\title{
Demonstration of Ecological Engineering and Eco-friendly Pest and Disease Management Strategies in Paddy
}

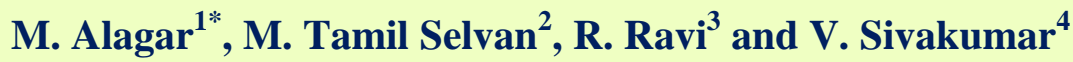 \\ ${ }^{1}$ Agricultural Entomology, ${ }^{4}$ Horticulture, \\ Coconut Research Station, TNAU, Aliyarnagar, India \\ ${ }^{2}$ Horticulture, Agricultural Research Station, TNAU, Pattukottai, India \\ ${ }^{3}$ Forestry, Forest College and Research Institute, TNAU, Mettupalayam, India \\ *Corresponding author
}

\section{A B S T R A C T}

\begin{tabular}{l} 
K e y w o r d s \\
$\begin{array}{l}\text { Ecofriendly, } \\
\text { ecological } \\
\text { engineering, paddy, } \\
\text { pest and disease } \\
\text { management }\end{array}$ \\
\hline Article Info \\
\hline $\begin{array}{l}\text { Accepted: } \\
\text { 15 July } 2020 \\
\text { Available Online: } \\
\text { 10 August } 2020\end{array}$ \\
\hline
\end{tabular}

Ecological Engineering and ecofriendly pest and disease management strategies in paddy is the need of the hour because of reduction in natural enemies population in rice ecosystem due to indiscriminate use of pesticides. Ecological Engineering and ecofriendly pest and disease management strategies in paddy was demonstrated in the farmers' field as Front Line Demonstration in Nagapattinam district of Tamil Nadu. In the demonstration plot the dead heart symptoms was $3.63 \%$ and white ear was $0.86 \%$ compared to $13.29 \%$ and $2.90 \%$ dead heart and white ears respectively in the farmers practices adopted plot. In the same manner the leaf folder damage was also low in the demonstration plots. The pest defender ratio was $0.75: 8$ in the demonstration plot and it was 4:1in the farmers practices adopted field. The per cent Disease Index (PDI) for blast was $0.73 \%$, PDI for Bacterial Leaf Blight (BLB) was $2.47 \%$ compared to $5.12 \%$ and $9.51 \%$ respectively in farmers practices adopted field. The PDI of false smut was $0.33 \%$ in the demo plot and it was $3.33 \%$ in the farmers practices adopted plot. In the demonstration plot the highest yield of $56.57 \mathrm{Q} / \mathrm{Ha}$ was recorded when compared to only $34.73 \mathrm{Q} / \mathrm{Ha}$ in the farmers practices adopted plot. The net return was Rs. 35,540/Ha whereas, in the farmers practices adopted plot the net return was only Rs.9,458/Ha. The benefit cost ratio was $1: 1.82$ in the demonstration plot and it was 1:1.24 in the non-demo plot.

\section{Introduction}

Paddy (Oryza sativa L.) is the stable food crop for 50 per cent of world population. About 90 per cent of paddy area is in Asia. Around 1373 insect pests are known to attack paddy crop. Among these, 20 to 30 insect pests are causing economic damage and causes reduction in yield up to 25 to $30 \%$.
Pest problems have increased tremendously due to monoculture, overlapping of crops, dense cropping and availability of preferred host. Intensive rice production with the primary goal of achieving high yield is often characterized by the excessive application of fertilizers and pesticides. It has led to many negative environmental effects, such as the reduction of biodiversity and natural 
biological control, high pesticide residues in rivers, drinking water and agricultural products, rapid and high insecticide resistance in pests, secondary pest outbreaks, environmental pollution and ecological imbalance. These severe negative effects will damage the ecosystem, lead to frequent pest outbreaks and in turn require an increased pesticide dosage, which form a vicious circle (Conway and Pretty, 1991).

Ecological engineering is a relatively new concept of habitat manipulation for the benefit of man and the environment. Habitat manipulation is growing nectar producing flowering plants combined with trap plants on the rice bounds, reducing the intensity of pesticide use and nitrogenous fertilizers, and managing the vegetation in non-rice habitats including the rice-free season (Sree Latha and Jesu Rajan, 2018).

The purpose of ecological engineering for pest management was to exploit the cultural practices, usually based on vegetation management, to enhance biological control. Alternative to chemical method is biological control and in ecological engineering concept, growing flowering plants is key component to provide resources such as nectar and pollen to natural enemies to promote biological control. It includes attractant plants to attract the natural enemies, repellent plants to repel the pests, trap plants to attract and trap the crop pests, barrier/guard plants to prevent the entry of pests. It also includes trap crops that divert pests away from crops and changing monocultures to polycultures in agroecosystem.

Keeping this in view the demonstration of Ecological engineering and ecofriendly pest and disease management strategies in paddy was demonstrated as Front Line Demonstration in the farmers field at Nagapattinam district of Tamil Nadu, India during Rabi season (October to January) 2016-17.

\section{Materials and Methods}

Front line demonstration was conducted at Nagapattinam district of Tamil Nadu during Rabi season (October to January) 2017-18. Nagapattinam district is located in Cauvery delta zone of Tamil Nadu and paddy is the major crop and cultivated in 1,60,440 hectares during Rabi season. The prioritized problems observed were reduction in natural enemies due to indiscriminate use of pesticides in rice ecosystem and lack of knowledge on eco friendly pest and disease management strategies among the rice growing farmers in the Nagapattinam district. There were 10 demonstrations one acre each. In the demonstration plot the following technologies were demonstrated. In the bunds of rice field the farmers were instructed to grow the sunflower, marigold, sesame and black gram for nectar and pollen sources for parasitoids and predators.

Neem cake was applied @ 250kg/Ha during last ploughing. The paddy seeds were treated with talc formulation of TNAU Pseudomonas fluorescens (pf1)@10 gm/Kg seeds. For the management of rice yellow stem borer, egg parasitoid, Trichogramma japonicum @ $5 \mathrm{cc} / \mathrm{Ha}$ were released at 30 and $37^{\text {th }}$ days after planting and yellow stem borer pheromone traps were installed 12 numbers/Ha. For the management of rice leaf folder, T. chilonis were released @ 5cc/Ha at 37, 44 and 51 days after planting. For the management of bacterial leaf blight and false smut - foliar spray of $P$. fluorescens @ $2.5 \mathrm{~kg} / \mathrm{Ha}$ and spray of fresh cow dung extract $20 \%$.

For the management of sucking pests Azadirachtin (10,000 ppm) @ $1250 \mathrm{ml} / \mathrm{Ha}$ were sprayed at the time of early infestation. Lecanicillium lecanii and Beuvaria bassiana 
were applied @ 5 kg/acre during active tillering stage and panicle initiation stage for the management of sucking pests and larval pests. The were about 250 bird perches were erected to attract the predatory birds and one light trap was installed (TNAU, 2012). The per cent pest and disease incidence, predator and parasitoid population were recorded in all the demonstration and farmers practices adopted plots during active tillering stage, panicle initiation stage, flowering and harvesting stage. Farmers were instructed to adopt all other recommended package of practices. The farmers were motivated about the ecological engineering and ecofriendly pest and disease management strategies through trainings, mass media and conducting field day for vertical spread of the technologies to the other farmers. The farmers were insisted to adopt these strategies on community basis and avoiding use of insecticides for building up of the beneficial insects for effective management of the pests. In the demonstration plot no inorganic pesticide were applied. The cost of the critical inputs was Rs.7500/Ha. The cost of cultivation and yield parameter were collected from the farmer at the end of the season and economic analyses were done using the prevailing input and output costs.

The extension gap, technology gap and technology index were worked out. To estimate the technology gap, extension gap and technology index, following formulae given by Samui et al., (2000) was used.

Technology gap = Potential yield $(q / h a)-$ Demonstration yield (q/ha)

Extension gap $=$ Demonstration yield $(\mathrm{q} / \mathrm{ha})-$ farmer's practice yield (q/ha).

Technology Index $=$ (Potential yield Demonstration yield) / Potential yield) x100

\section{Results and Discussion}

The results from table 1 revealed that in the demonstration plot the dead heart was $3.63 \%$ and white ear was $0.86 \%$ compared to $13.29 \%$ and $2.90 \%$ dead heart and white ears respectively in the farmers practices adopted plot. In the same manner the leaf folder damage was also low in the demonstration plot. The pest defender ratio was $0.75: 8$ in the demonstration plot and it was 4:1in the farmers practices adopted field.

The Per cent Disease Index (PDI) for blast was 0.73 and PDI for Bacterial Leaf Blight (BLB) was 2.47 compared to 5.12 and 9.51 respectively in farmers practices. The PDI of false smut infestation was $0.33 \%$ in the demonstration plot and it was $3.33 \%$ in the farmers practices adopted plot (Figure 1). In the demonstration plot the highest yield of $56.57 \mathrm{Q} / \mathrm{Ha}$ was recorded as compared to only 34.73 Q/Ha. The net return was Rs. 35,540/ha whereas, in the farmers practices adopted plot the net return was Rs.9,458/Ha. The benefit cost ratio was 1:1.82 in the demonstration plot and it was 1:1.24 in the non-demo plot (Table 2 ). The results in table 3 revealed that the technology gap was $5.98 \mathrm{Q}$./ha, the extension gap was $21.84 \mathrm{Q} / \mathrm{ha}$ and the technology index was $9.56 \%$.

In the present study the pests and diseases incidence was significantly low in the demonstration plots when compare to farmers practices adopted plot. It might be due to the pest defender ratio was more in the demonstration plot i.e. natural enemies population was more compared to pest load. It might kept the pests under control. The border or bund crops like sesame, marigold, black gram and sunflowers might supported the multiplication and survival of natural enemies. The bund crops might provided pollen and nectar for natural enemies. Earlier studies also supported this finding. Nectar 
food management can not only increase the longevity and improve the reproduction of natural enemies, but also plays a role in enhancing the biological control ability of natural enemies (Wackers et al., 2005).

In China, growing the flowering plant sesame (Sesamum indicum) on rice field bund and road side to improve biological control has been listed as a main component of the nationally recommended sustainable management of rice insect pests by ecological engineering ( $\mathrm{Lu}$ and Guo, 2015). Y-tube olfactometer assays indicated that the egg parasitoids Anagrus optabilis and Anagrus nilaparvatae are significantly attracted by the volatiles from sesame. Similarly, both of these two parasitoids significantly parasitize more BPH eggs in the presence of sesame flowers (Zhu et al., 2012).

The predatory bug Cyrtorhinus lividipennis is an important natural enemy of rice planthopper eggs and young nymphs (Katti et al., 2007; Sigsgaard, 2007). The adult longevity of $C$. lividipennis with access to sesame flowers can be extend, along with significantly increased egg consumption and strongly promoted predation (Zhu et al., 2014). Meanwhile, the real fecundity of Trichogramma chilonis, a common egg parasitoid of Lepidoptera pests, is significantly increased by sesame flowers.
Non-rice habitats, as refuges and pools of arthropods in rice ecosystem, play important roles in the reconstruction and development of arthropod community in rice fields ( $\mathrm{Yu}$ et al., 1996; Zhang et al., 1997; Gu et al., 1999). Bunds and other non-rice habitats are rich in natural control resources and can effectively regulate the pest populations in rice fields $(\mathrm{Li}$ et al., 2002). An arthropod investigation in rice fields and adjacent non-rice habitats showed that parasitoid species in rice fields and non-rice habitats accounted for $45.89 \%$ and $46.60 \%$ of the total natural enemy species, respectively (Xu et al., 2004). There are huge populations of Oligosita spp. on gramineous flora, such as Digitaria anguinalis and Eleusine indica, and there are abundant of Anagrus spp. Field studies conducted with different flowering plants suggested that growing of sesame, bhendi, sunflower and sunhemp attracts large number of predators and parasitoids like coccinellids, ground beetles, Anagrus species, Bracon species etc., which attack the pests (Sree Latha and Jesu Rajan, 2018). Habitat manipulation aims to provide resources such as pollen (Hickman and Wratten 1996), nectar (Baggen and Gurr, 1998), alternative prey, physical refugia (Halaji et al., 2000), alternative hosts, lekking sites (Sutherland et al., 2001) and (Viggiani, 2003) to the natural enemies.

Table.1 Comparative analysis of Pests incidence and natural enemies in the demonstration and in farmers practice plot

\begin{tabular}{|l|c|c|}
\hline \multicolumn{1}{|c|}{ Parameters } & Demonstration plot* & $\begin{array}{c}\text { Farmers practice } \\
\text { plot } *\end{array}$ \\
\hline \% dead heart & 3.63 & 13.29 \\
\hline \% white ear & 0.86 & 2.90 \\
\hline \% leaf folder damage (vegetative) & 2.79 & 11.92 \\
\hline \% leaf folder damage (flowering) & 1.14 & 7.28 \\
\hline Pest Defender Ratio & $0.75: 8$ & $4: 1$ \\
\hline
\end{tabular}

* Mean of ten demonstrations 
Table.2 Economic analysis of cost and returns in the demonstration and in check plot

\begin{tabular}{|l|c|c|}
\hline \multicolumn{1}{|c|}{ Parameters } & Demonstration plot* & $\begin{array}{c}\text { Farmers } \\
\text { practice } \\
\text { plot } * *\end{array}$ \\
\hline Gross cost of cultivation (Rs./Ha.) & 43,658 & 39,167 \\
\hline Yield (Q/Ha.) & 56.57 & 34.73 \\
\hline Gross income (Rs./Ha.) & 79,198 & 48,625 \\
\hline Net return (Rs./Ha.) & 35,540 & 9,458 \\
\hline Benefit Cost Ratio & 1.82 & 1.24 \\
\hline
\end{tabular}

* Mean of ten demonstrations

Table.3 Technology gap, extension gap and technology Index of Ecological Engineering IPM paddy

\begin{tabular}{|c|c|c|c|c|c|}
\hline $\begin{array}{c}\text { Potential yield } \\
\text { (Q./Ha.) }\end{array}$ & $\begin{array}{c}\text { Demonstration } \\
\text { yield (Q./Ha.) }\end{array}$ & $\begin{array}{c}\text { Farmers } \\
\text { practice yield } \\
\text { (Q./Ha.) }\end{array}$ & $\begin{array}{c}\text { Technology } \\
\text { gap (Q./Ha.) }\end{array}$ & $\begin{array}{c}\text { Extension } \\
\text { gap (Q./Ha.) }\end{array}$ & $\begin{array}{c}\text { Technology } \\
\text { index (\%) }\end{array}$ \\
\hline $\mathbf{6 5 . 5 3}$ & 56.57 & 34.73 & 5.98 & 21.84 & 9.56 \\
\hline
\end{tabular}

* Mean of ten demonstrations

Figure.1 Comparative analysis of Per cent Disease Index (PDI) in the demonstration and check plot

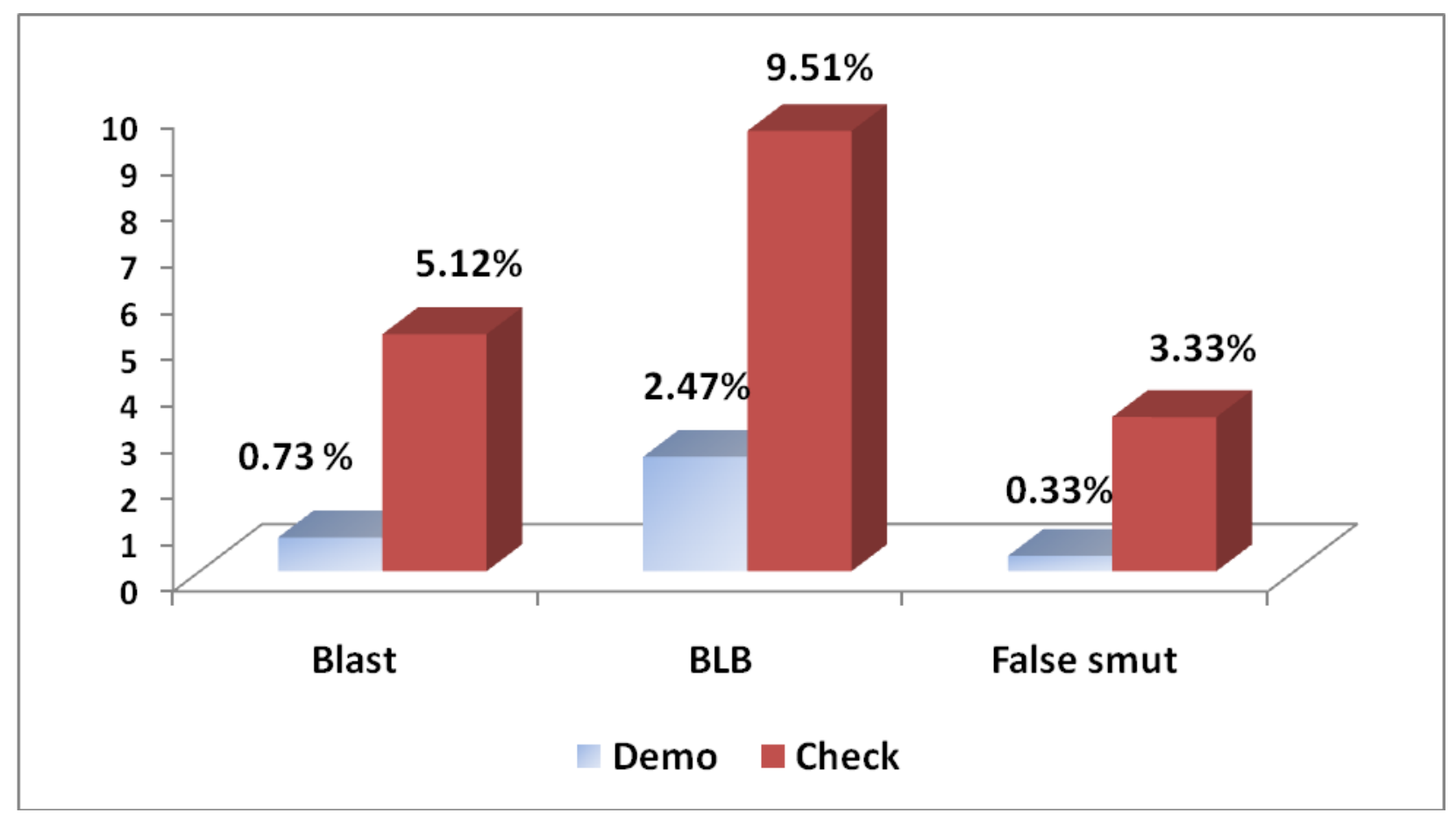


The technology gap in the demonstration yield over potential yield were $5.98 \mathrm{Q} / \mathrm{ha}$. The technological gap may be attributed to the dissimilarity in the soil fertility status. The latest technologies will eventually lead the farmers to discontinue the traditional technology and to adopt new technology. The extension gap was $21.84 \mathrm{Q} /$ ha during the period of study which emphasized the need to educate the farmers through various means for the adoption of improved agricultural production to reverse the trend of wide extension gap. The technology index was 9.56 percent which showed the feasibility of the evolved technology at the farmer's field. Tiwari et al., (2015) reported that the lower the value of technology index, the more is the feasibility of the technology.

In conclusion, experimentation with ecological engineering is revealed that it offers immense opportunities to rice pest management using non-chemical methods leading to economic and environmental benefits. Ecological engineering is not a "high-tech" approach so simple and practical for rice farmers to implement. For the successful implementation of this technology motivating the farmers to follow these ecofriendly approaches on community basis is essential. A collective approach by the farming community will not only suppress the pest population but also enhances the soil micro flora and enrich the soil with organic matter.

\section{References}

Baggen LR and Gurr GM (1998). The influence of food on Copidosoma koehleri, and the use of flowering plants as a habitat management tool to enhance biological control of potato moth, Phthorimaea operculella. Biological Control. 11 (1):9-17.

Conway GR and Pretty JN (1991).
Unwelcome Harvest: In: Agriculture and Pollution. London: Earth scan Publications Ltd. for use in ecological engineering to promote biological control of rice pests by the predatory bug, Cyrtorhinus lividipennis (Heteroptera: Miridae). PLoS One, 9(9): e108669.

Gu DX, Zhang GR, Zhang WQ, Qu, DS and $\mathrm{R}$ Wen (1999). The reestablishment of the spider community and the relationship between spider community and its species pool in paddy fields. Acta Arachnol Sin, 8(2): 89-94.

Halaji J, Cady, AB and GW Uetz (2000). Modular habitat refugia enhance generalist predators and lower plant damage in soybeans, Environmental Entomology, 29:383-393.

Hickman, JM and SD Wratten (1996). Use of Phacelia tanacetifolia strips to enhance biological control of aphids by hoverfly larvae in cereal fields', Journal of Economic Entomology, 89:832-840.

Katti GI and Pasalu Padmakumari AP (2007). Biological Control of Insect Pest of Rice. India: Directorate of Rice Research: 22 p.

Li ZS, Xu, DM, Zhuang, J.X Wei GR, Huang YY and Liu YF (2002). Investigation on parasitoid resource on weeds around paddy field. Wuyi Sci J, 18(1): 19-23.

Lu ZX and Guo R (2015). Ecological engineering methods to manage rice insect pests. In:. Agricultural Leading Varieties and Mainstay Technologies in 2015. Beijing: Ministry of Agriculture China Agricultural Press: 274 p.

Samui S K, Mitra, S, Roy D K, Mandal A K and Saha D (2000). Evaluation of front line demonstration on groundnut. $J$ Indian Soc Coastal Agric Res 18(2): 180-183

Sigsgaard, L (2007). Early season natural control of the brown planthopper, Nilaparvata lugens: The contribution 
and interaction of two spider species and a predatory bug. Bull Entomol Res, 97(5): 533-544.

Sreelatha, E and S Jesu Rajan (2018). Ecological Engineering for Sustainable Agriculture: Simple Concept with Greater Impact. International Journal of Scientific and Research Publications, 8 (2):123-125.

Sutherland JP, Sullivan MS, and Poppy GM (2001). Distribution and abundance of aphidophagous hoverflies (Diptera: Syrphidae) in wildflower patches and field margin habitats, Agricultural and Forest Entomology 3:57-64.

Tamil Nadu Agricultural University (2012). Crop Production Guide. 388 p.

Tiwari B K, Tiwari K P, Sahare K V and Tripathi P N (2015). Impact of front line demonstration of management practices on wheat under irrigated conditions. Plant Archives 15 (2): 1079-1082

Viggiani, G (2003). Functional biodiversity for the vineyard agroecosystem: aspects of the farm and landscape management in Southern Italy. Bulletin Oilb.Srop. 26(4):197-202.

Wackers FL, Van Rijn PCJ and Bruin J. (2005). Plant-provided food for carnivorous insect: A protective mutualism and its applications. UK:
Cambridge University Press: 356 p.

Xu DM, Li ZS Liu YF and You MS (2004). Structure and characteristics of parasitoid communities in a rice field and adjacent weed habitat. Biodiv Sci, 12(3): 312-318.

$\mathrm{Yu}$ XP, Hu C and Heong KL (1996). The effects of non-crop habitats on crop pests and their natural enemies. Chin $J$ Biol Control, 12(3): 130-133.

Zhang GR, Gu DX and Zhang WX (1997). Species pools of predatory arthropod communities and community rebuilding in paddy fields. Chin J Biol Control, 13(2): 65-68.

Zhu PY, Lu ZX, Heong KL, Chen GH, Zheng $\mathrm{XS}, \mathrm{Xu} \mathrm{HX}$, Yang YJ, Nicol $\mathrm{HI}$ and Gurr GM (2014). Selection of nectar plants for use in ecological engineering to promote biological control of rice pests by the predatory bug, Cyrtorhinus lividipennis (Heteroptera: Miridae). PLoS One, 9(9): e108669.

Zhu PY, Lu ZX, Gurr G, Zheng XS, Read D, Yang YJ and Xu HX (2012). Ecological functions of flowering plants on conservation of the arthropod natural enemies of insect pests in agroecosystem. Chin J Biol Control, 28(4): 583-588.

\section{How to cite this article:}

Alagar, M., M. Tamil Selvan, R. Ravi and Sivakumar, V. 2020. Demonstration of Ecological Engineering and Eco-friendly Pest and Disease Management Strategies in Paddy. Int.J.Curr.Microbiol.App.Sci. 9(08): 1261-1267. doi: https://doi.org/10.20546/ijcmas.2020.908.142 